\title{
Aroma of mature-green and tree-ripe mangoes after refrigerated air or controlled atmosphere storage
}

\section{Renar João Bender ${ }^{1 *}$ Jeffrey Karl Brecht ${ }^{2} \odot$ Elizabeth Amory Baldwin ${ }^{3}$}

\author{
${ }^{1}$ Laboratório de Pós-Colheita, Faculdade de Agronomia, Universidade Federal do Rio Grande do Sul (UFRGS), 91540-000, Porto Alegre, RS, \\ Brasil. E-mail: rjbe@ufrgs.br. "Corresponding author. \\ ${ }^{2}$ Horticultural Sciences Department, Institute of Food and Agricultural Sciences (IFAS), University of Florida (UF), Gainesville, FL, United \\ States of America. \\ ${ }^{3}$ U. S. Horticultural Research Laboratory, Fort Pierce, FL, United States of America.
}

\begin{abstract}
Mango flavor is dependent on cultivar characteristics and postharvest handling procedures. Mangoes harvested with the ripening metabolism initiated develop better flavor than mangoes harvested at the mature-green stage. Different cultivars were harvested at both ripeness stages and evaluated to determine the effect of fruit ripeness, storage temperature and atmosphere on the volatiles present in aroma profiles. Mangoes of the cultivars Haden, Keitt and Tommy Atkins at distinct ripeness stages were stored in controlled atmospheres (CA) with 2, 5 or $21 \mathrm{kPa} \mathrm{O}_{2}$ plus 0,10 or $25 \mathrm{kPa} \mathrm{CO}$ at $5,8,12$ or $15^{\circ} \mathrm{C}$. Terpene concentrations of mangoes stored in air were higher than the concentrations in mangoes stored in CA. The sesquiterpene $\alpha$-copaene did not present recognizable peaks in almost all elusion sequences. The same result was observed with the monoterpene $\beta$-pinene in $c v$. Haden and cv. Keitt mangoes while in 'Tommy Atkins' fruit $\beta$-pinene concentrations were below $1.06 \mu \mathrm{LL} \mathrm{L}^{-1}$. Ethanol and acetaldehyde concentrations were significantly higher in mangoes from $2 \mathrm{kPa} \mathrm{O}_{2}$ storage than those from air storage or the other CA treatments. Terpene synthesis in air or CA storage in all cultivars varied significantly, preventing generalizations as to what storage conditions favor or limit aroma components elution.

Key words: Mangifera indica L., terpenes, 3-carene, elevated $\mathrm{CO}_{2}$, volatile compounds.
\end{abstract}

Complexo aromático de mangas pré-climatéricas e maduras armazenadas em ar refrigerado ou atmosfera controlada

RESUMO: O complexo aromático de mangas resulta das caracteristicas de cada cultivar e do manejo pós-colheita dos frutos. Mangas colhidas em estádio de maturação mais avançado desenvolvem um aroma melhor que mangas colhidas no estádio pré-climetérico. Para o presente trabalho diferentes cultivares de mangas foram colhidas em ambos estádios de maturação e avaliadas para os efeitos destes estádios e da atmosfera de armazenagem nos compostos voláteis presentes no perfil de aroma. Mangas das cultivares Haden, Keitt e Tommy Atkins, em distintos estádios de maturação, foram armazenadas em ar refrigerado ou em atmosfera controlada (AC) com 2, 5 ou $21 \mathrm{kPa} \mathrm{O}_{2}$ misturado a 0,10 , ou $25 \mathrm{kPa} \mathrm{CO}$ com temperaturas de 8,12 ou $15{ }^{\circ} \mathrm{C}$. As concentrações de terpenos em mangas armazenadas em ar refrigerado foram mais elevadas que as concentrações determinadas em armazenagem em AC. O sesquiterpeno $\alpha$-copaeno não apresentou picos reconheciveis em nenhum dos cromatogramas de mangas dos diferentes tratamentos. O mesmo comportamento foi observado com o $\beta$-pineno nas cv. Haden e Keitt, enquanto que na cv. Tommy Atkins este monoterpeno apresentou picos de eluição abaixo $1.06 \mu \mathrm{LL}^{-1}$. Concentrações de etanol e acetaldeído foram significativamente maiores em mangas armazenadas em $\mathrm{AC}$ de $2 \mathrm{kPa} O$, na comparação com armazenagem em ar e com as demais concentrações de AC. A biossintese de terpenos em armazenagem, tanto em ar refrigerado como em AC, variou consideravelmente de modo que deve-se evitar generalizações sobre quais condições de armazenagem favorecem ou limitam a composição do complexo aromático em mangas.

Palavras-chave: Mangifera indica L., terpenos, 3-carene, elevado $\mathrm{CO}_{2}$, compostos aromáticos.

\section{INTRODUCTION}

Presence of tropical fruits, mangoes amongst those, on international markets is increasing yearly (MONACO et al., 2016). Mangoes are one of the most important tropical fruits in world trade (LI et al., 2017). Popularity outside of tropical areas has become a certainty because of continuous availability.
Mangoes' unique flavor and production areas spread all over tropical and subtropical areas in the world have converted its status from that of a specialty fruit to a staple (SIVAKUMAR et al., 2011).

The mango industry did not develop a handling procedure for its own use, but rather adapted the practices of the deciduous fruit industry by harvesting the fruit at the pre climacteric ripeness 
stage (i.e., mature green) and using temperature management and exclusion of ethylene to delay the onset of ripening until after the fruit have reached destination markets.

The mango industry has settled on harvesting the fruit at less ripe stages to extend shelf life, thus, facilitating supply of distant markets even though there are negative consequences for flavor (BALOCH \& BIBI, 2012). Mango flavor is dependent on cultivar characteristics, but is also affected by ripeness stage at harvest. Postharvest handling procedures may also affect internal fruit quality (SIVAKUMAR et al., 2011; BRECHT, 2020). LEBRUN et al. (2008) confirmed that mangoes harvested at the tree-ripe stage (i.e., with ripening initiated) develop better flavor than mangoes harvested at the mature-green stage.

There have been studies with different approaches to characterize mango flavor components. By the combination of three analytical methods ENGEL \& TRESSL (1983), characterized 114 components in two of the most important Asian cultivars: Alphonso and Baladi. Similarly, MacLEOD \& SNYDER (1985) evaluated the cultivars Tommy Atkins and Keitt at different ripeness stages and found great variation in aroma profiles, especially with respect to the major monoterpenes. BARTLEY \& SCHWEDE (1987) concluded that as mangoes ripen in storage the increase in concentrations of higher esters is noteworthy.

LALEL et al. (2003) concluded that ripe cv. Kensington Pride mangoes exhibited higher amounts of aroma volatiles than mangoes harvested at a less ripe stage. LEBRUN et al. (2008) corroborated that statement with three mango cultivars harvested at two ripeness stages. PANDIT et al. (2009) analyzed fruit of 'Alphonso' mangoes at five ripeness stages and concluded that during the transition from unripe to ripe qualitative and quantitative compound changes contribute to unique volatile signatures. MUNAFO et al. (2016) identified 34 aroma compounds in tree-ripe mangoes previously linked to high flavor dilution factors.

Despite all the work on mango aroma profiles, there have not been many studies to evaluate the effect of different storage conditions on individual components of the mango aroma profile beyond our previous research with mature-green and treeripe cv. Tommy Atkins mangoes stored in CA at 8 ${ }^{\circ} \mathrm{C}$ or $12{ }^{\circ} \mathrm{C}$ (BENDER et al., 2000a). LALEL et al. (2003) determined that storage of mature-green 'Kensington Pride' mangoes in $2 \mathrm{kPa} \mathrm{O}_{2}$ combined with $\mathrm{CO}_{2}$ up to $9 \mathrm{kPa}$ at $13{ }^{\circ} \mathrm{C}$ reduced total aroma volatiles, monoterpenes, sesquiterpenes and aromatic compounds after fruit ripening. ULLAH et al. (2010) indicated that fully ripe $\mathrm{cv}$. Alphonso mangoes stored in $3 \mathrm{kPa} \mathrm{O}$ plus $6 \mathrm{kPa} \mathrm{CO}$ for 3 weeks at $10{ }^{\circ} \mathrm{C}$ had better flavor as indicated by sensory panelists in comparison to air storage or higher $\mathrm{CO}_{2}$ partial pressures. GOSWAMI \& RAVINDRA (2013) observed that mature-green cv. Amrapali mangoes stored in $\mathrm{CO}_{2}$ partial pressures as high as $8 \mathrm{kPa}$ presented limited volatile production, especially hydrocarbons and esters after storage at $12{ }^{\circ} \mathrm{C}$ plus 5 days of ripening at $21^{\circ} \mathrm{C}$.

Therefore, aroma volatiles from different mango cultivars, harvested at different ripeness stages, that had been stored for up to 3 weeks in various combinations of temperature and CA storage conditions were evaluated in order to determine the effect of fruit ripeness stage, storage temperature, and storage atmosphere on the production of the most predominant volatiles present in mango aroma profiles.

\section{MATERIALS AND METHODS}

The determination of aroma volatiles was performed on fruit from 'Keitt', 'Tommy Atkins' and 'Haden' mango cultivars of different ripeness stages that had been stored under different atmospheres and at different storage temperatures. 'Keitt' mangoes at the tree-ripe stage were harvested from Gulf Island Grove at Pine Island/Fort Myers, Florida. Mature green and tree ripe 'Tommy Atkins' mangoes were harvested from a grove of Brooks Tropicals, Homestead, Florida. Selection for harvest and ripeness stage was based on ground color and on fruit shape, i.e. the outgrowing of the shoulders as described in MILLER et al. (1986): mature-green corresponds to hard fruit, well-formed and with totally green skin ground color (RS1) and tree-ripe fruit are firm, well-formed and with some yellow ground color development (RS3).

The fruit were placed into 10.05-L glass jars, four fruit per jar, upon arrival at the laboratory. Three treatments, with three replicate jars per treatment, were exposed via the flow-through system to $5 \mathrm{kPa} \mathrm{O}_{2}$ plus either $10 \mathrm{kPa}$ or $25 \mathrm{kPa} \mathrm{CO}$ or an air control. The tree ripe 'Tommy Atkins' mangoes were stored for 21 days at $8{ }^{\circ} \mathrm{C}$ or $12^{\circ} \mathrm{C}$ while the mature green mangoes were only stored at $12{ }^{\circ} \mathrm{C}$. The tree ripe 'Keitt' mangoes were stored at $8{ }^{\circ} \mathrm{C}$ or $5{ }^{\circ} \mathrm{C}$ also for 21 days. After the period of CA storage, fruit of both cultivars were maintained for 3 days in air at $20^{\circ} \mathrm{C}$.

'Haden' mangoes were imported from Peru and 'Tommy Atkins' from Brazil by Brooks 
Tropicals in Homestead, Florida and transported to Gainesville by refrigerated truck. These mangoes were harvested at the mature-green ripeness stage and handled at the origin under normal commercial conditions, treated with $46.1^{\circ} \mathrm{C}$ water for 60 minutes for insect disinfestation, and coated with a commercial formulation of carnauba wax prior to marine shipment to Florida. After arrival at the Postharvest Laboratory/ Horticultural Sciences Department, University of Florida, the mangoes were selected for freedom from defects, and immediately placed in glass jars and transferred to storage rooms.

'Haden' mangoes were held in 1.75-L glass jars, one fruit/jar, with either air or CA applied in a flow-through system for 14 days at $15^{\circ} \mathrm{C}$, with six replicate jars per treatment. Air, delivered by a compressor, was mixed with nitrogen $\left(\mathrm{N}_{2}\right)$ from a cylinder to produce treatments of $2 \mathrm{kPa}$ and $5 \mathrm{kPa}$ $\mathrm{O}_{2}$. Control treatment was air in the flow-through system. A treatment of $25 \mathrm{kPa} \mathrm{CO}$, was obtained by combining air with $\mathrm{CO}_{2}$ delivered by a cylinder. The same CA treatments were applied to 'Tommy Atkins' mangoes for 21 days at $12{ }^{\circ} \mathrm{C}$. In this experiment, there were four fruit per 10.05 -L glass jar and four replicate jars per treatment.

Mesocarp tissues of mature green and treeripe 'Tommy Atkins' and tree-ripe 'Keitt' mangoes were homogenized after the three-days at $20{ }^{\circ} \mathrm{C}$ ripening period. Tissues of the imported mature-green 'Haden' and 'Tommy Atkins' mangoes were homogenized upon retrieval from CA storage. A $50 \%(\mathrm{w} / \mathrm{v})$ homogenate was prepared by mixing equal amounts of tissue and deionized water. The diluted samples were stored at -20 ${ }^{\circ} \mathrm{C}$ until used for volatile determinations.

Volatile components were quantified based on the procedure of BALDWIN et al. (1991) and modified by MALUNDO et al. (1997) using a Perkin-Elmer GC (Foster City, CA), model 8500, equipped with a model HS-6 headspace sampler, a flame ionization detector and a $0.53 \times 3000 \mathrm{~mm}$ polar Durowax column (J \& W Scientific, Folsom, CA). The concentrations of the volatiles were calculated using regression equations fitted to peak height calibration curves as described in MALUNDO et al. (1997) except for acetaldehyde, ethanol and hexanal, for which there were no calibration curves prepared. Those compounds are presented as peak heights.

Data were analyzed via analysis of variance (ANOVA) and correlation coefficients determined using SAS for PC (SAS Inst., Cary, NC). The experiments were conducted in completely randomized designs and averages separated at a $\mathrm{P}<0.05$ by Tukey's multiple range test.

\section{RESULTS AND DISCUSSION}

The components determined in the present research with cv. Keitt and Tommy Atkins and Haden mangoes were predominantly monoterpenes and sesquiterpenes, confirming the conclusions of MacLEOD \& SNYDER (1985), who also worked with 'Tommy Atkins' and 'Keitt' mangoes. MacLEOD $\&$ PIERIS (1984), likewise, identified terpenes as the most abundant volatiles in cv. Jaffna, cv. Parrott and cv. Willard mangoes and PANDIT et al. (2009), in trials with cv. Alphonso mangoes at different ripeness stages corroborated the conclusions on terpenes in mango aroma profiles.

The terpenes that were quantified in the present research probably are, according to MALUNDO et al. (1997), the most critical for mango flavor, even though WILSON et al. (1990) concluded that a characteristic component for mango flavor can not be determined, considering the complexity of the mixture of components in a mango volatile profile. ADEDEJI et al. (1992) reiterated this conclusion. PANDIT et al. (2009), SINGH \& SAINI (2014), LI et al. (2017) and ZAFAR \& SIDHU (2017) add further that the variability in the mango aroma complex and chemical and nutritional profiles also depend on growing conditions, rootstock, ripeness stage at harvest, and storage atmosphere composition.

In the samples of 'Keitt' mangoes stored for 21 days at $5{ }^{\circ} \mathrm{C}$ or $8{ }^{\circ} \mathrm{C}$, then analyzed after 3 days in air at $20^{\circ} \mathrm{C}$, the fruit stored in the $25 \mathrm{kPa}$ $\mathrm{CO}_{2}$ atmosphere at $5{ }^{\circ} \mathrm{C}$ had significantly higher levels of $\alpha$-pinene, 3 -carene, limonene and myrcene (Table 1). The terpinolene contents (Table 2) was also significantly higher in mangoes of the $25 \mathrm{kPa}$ $\mathrm{CO}_{2}$ atmosphere when compared with air storage or $10 \mathrm{kPa} \mathrm{CO}$ and the initial values determined prior to storage. In contrast, $P$-cymene was completely absent in the mangoes from the $25 \mathrm{kPa} \mathrm{CO}_{2}$ storage atmosphere and caryophyllene synthesis apparently is not influenced by the elevated $\mathrm{CO}_{2}$ atmospheres. The component that has been determined to be the most abundant in 'Tommy Atkins', 'Keitt' and 'Kent', the three Florida-type mangoes examined by MALUNDO et al. (1997) is 3-carene, a monoterpene hydrocarbon (ADEDEJI, 1992), which was also confirmed in our experiments.

In the experiments with mature-green 'Haden' and 'Tommy Atkins' mangoes in which the response to the reduction of $\mathrm{O}_{2}$ partial pressures was tested, there were differences in volatile elution from mesocarp tissue when sampled on the day of 
Table 1 - Aroma compounds, in $\mu \mathrm{LL}^{-1}$, in mesocarp tissues of tree ripe cv. Keitt mangoes at beginning of storage and after 3 days in air at $20{ }^{\circ} \mathrm{C}$ following a 21 -day storage in $\mathrm{CA}\left(5 \mathrm{kPa} \mathrm{O}_{2}\right.$ plus $10 \mathrm{kPa}$ or $\left.25 \mathrm{kPa} \mathrm{CO}_{2}\right)$ or air at $5^{\circ} \mathrm{C}$ or $8{ }^{\circ} \mathrm{C}$.

\begin{tabular}{|c|c|c|c|c|c|}
\hline & $\alpha$-pinene & 3-carene & Limonene & $P$-cymene & Myrcene \\
\hline Initial value & 0.0303 & 3.945 & 0.0630 & 0.0037 & 0.4571 \\
\hline Air $-5^{\circ} \mathrm{C}$ & $0.0327 \mathrm{~b} /{ }^{1}$ & $3.153 \mathrm{~b}$ & $0.0527 \mathrm{~b}$ & $0.0046 \mathrm{~b}$ & $0.3296 \mathrm{~b}$ \\
\hline Air $-8^{\circ} \mathrm{C}$ & $0.0410 \mathrm{~b}$ & $3.984 \mathrm{~b}$ & $0.0672 \mathrm{~b}$ & $0.0098 \mathrm{a}$ & $0.3792 \mathrm{~b}$ \\
\hline $10 \mathrm{kPa} \mathrm{CO}_{2} 5^{\circ} \mathrm{C}$ & $0.0260 \mathrm{~b}$ & $3.578 \mathrm{~b}$ & $0.0583 \mathrm{~b}$ & $0.0061 \mathrm{~b}$ & $0.3374 \mathrm{~b}$ \\
\hline $25 \mathrm{kPa} \mathrm{CO}_{2} 5^{\circ} \mathrm{C}$ & $0.1725 \mathrm{a}$ & $6.569 \mathrm{a}$ & $0.0959 \mathrm{a}$ & $0.0000 \mathrm{c}$ & $0.6167 \mathrm{a}$ \\
\hline $\mathrm{CV}^{\prime 2}$ & 110.21 & 35.87 & 30.88 & 73.69 & 33.35 \\
\hline
\end{tabular}

${ }^{/ 1}$ Averages followed by the same letter in columns do not differ statistically at Tukey's multiple range test $(\mathrm{P}<.05)$

${ }^{12} \mathrm{CV}=$ variation coefficient.

transfer to air at $20^{\circ} \mathrm{C}$ after 14 or 21 days of storage (Table 3). 'Haden' had higher levels of 3-carene as well as limonene, $P$-cymene and, to some extent, myrcene than did 'Tommy Atkins'. According to the observations of BANDYOPADHYAY \& GHOLAP (1973) this difference could be a consequence of the higher storage temperature $\left(15^{\circ} \mathrm{C}\right)$ used for 'Haden' fruit compared with 'Tommy Atkins' $\left(12^{\circ} \mathrm{C}\right)$. But then, $\alpha$-pinene, also a terpenoid hydrocarbon (IDSTEOM \& SCHREIER, 1985), and therefore, supposedly derived from the same general pathway of 3-carene as indicated by their high partial correlation coefficient (0.963), was considerably higher in 'Tommy Atkins' than in 'Haden'. These observations indicate that cultivar differences are also major factors concerning the differences in aroma compounds, though that observation does not hold through for caryophyllene and terpinolene, which varied in about the same range in both cultivars (Table 4).

Cultivar differences were also observed in relation to $\beta$-pinene and $\alpha$-copaene. Whereas in 'Haden' and 'Keitt' mangoes elution sequences scarcely presented $\beta$-pinene peaks, in 'Tommy Atkins' mesocarp homogenates $\beta$-pinene concentrations varied from 0.10 to $0.23 \pm 0.072 \mu \mathrm{L}^{-1}$. The $\alpha$-copaene concentrations in 'Keitt' mangoes ranged from 0.034 to $0.127 \pm 0.075 \mu \mathrm{L} \cdot \mathrm{L}^{-1}$ after 21 days at 5 ${ }^{\circ} \mathrm{C}$ or $8{ }^{\circ} \mathrm{C}$ plus 3 days in air at $20{ }^{\circ} \mathrm{C}$. In contrast, in 'Haden' and 'Tommy Atkins' fruit $\alpha$-copaene was not detected after retrieval from storage.

Peak heights of hexanal for 'Haden' were generally much greater than for 'Tommy Atkins'

Table 2 - Aroma compounds in mesocarp tissues of tree ripe cv. Keitt mangoes at beginning of storage and after 3 days in air at $20{ }^{\circ} \mathrm{C}$ following a 21-day storage in $\mathrm{CA}\left(5 \mathrm{kPa} \mathrm{O}\right.$ plus $10 \mathrm{kPa}$ or $\left.25 \mathrm{kPa} \mathrm{CO}_{2}\right)$ or air at $5^{\circ} \mathrm{C}$ or $8{ }^{\circ} \mathrm{C}$.

\begin{tabular}{|c|c|c|c|c|c|}
\hline & Caryophyllene & Terpinolene & Acetaldehyde & Ethanol & Hexanal \\
\hline & \multicolumn{2}{|c|}{ 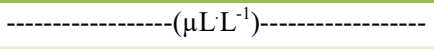 } & \multicolumn{3}{|c|}{ 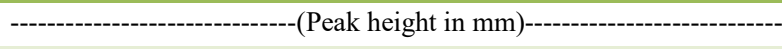 } \\
\hline Initial value & 0.3409 & 0.0731 & 593.21 & 762.74 & 112.77 \\
\hline Air- $5^{\circ} \mathrm{C}$ & $1.4650 \mathrm{a}^{/ 1}$ & $0.0612 \mathrm{~b}$ & $1,270.46 \mathrm{~b}$ & $2,872.98 \mathrm{~b}$ & $293.02 \mathrm{a}$ \\
\hline Air $-8^{\circ} \mathrm{C}$ & $0.3462 \mathrm{~b}$ & $0.0686 \mathrm{~b}$ & $1,471.63 \mathrm{~b}$ & $4,323.68 \mathrm{~b}$ & $303.50 \mathrm{a}$ \\
\hline $10 \mathrm{kPa} \mathrm{CO}{ }_{2}-5^{\circ} \mathrm{C}$ & $0.2689 \mathrm{~b}$ & $0.0462 \mathrm{~b}$ & $808.40 \mathrm{~b}$ & $2,233.54 \mathrm{~b}$ & $161.02 \mathrm{~b}$ \\
\hline $25 \mathrm{kPa} \mathrm{CO}-5^{\circ} \mathrm{C}$ & $0.2648 \mathrm{~b}$ & $0.1227 \mathrm{a}$ & $18,270.63 \mathrm{a}$ & $186,948.5 \mathrm{a}$ & $64.49 \mathrm{c}$ \\
\hline $\mathrm{CV}^{12}$ & 100.33 & 41.27 & 145.53 & 169.18 & 54.9 \\
\hline
\end{tabular}

\footnotetext{
${ }^{/ 1}$ Averages followed by the same letter in columns do not differ statistically at Tukey's multiple range test $(\mathrm{P}<.05)$.
}

${ }^{/ 2} \mathrm{CV}=$ variation coefficient. 
Table 3 - Aroma compounds, $\mu \mathrm{LL}^{-1}$, in mesocarp tissue of harvested mature-green cv. Haden and Tommy Atkins mangoes at transfer to $20{ }^{\circ} \mathrm{C}$ from air storage or in $\mathrm{CA}$ of $5 \mathrm{kPa} \mathrm{O}_{2}$ plus $10 \mathrm{kPa}$ or $25 \mathrm{kPa} \mathrm{CO}_{2}$ for 2 weeks at $15^{\circ} \mathrm{C}$ or 3 weeks at $12{ }^{\circ} \mathrm{C}$, respectively.

\begin{tabular}{|c|c|c|c|c|c|}
\hline & $\alpha$-pinene & 3-carene & Limonene & $P$-cymene & Myrcene \\
\hline \multicolumn{6}{|c|}{ 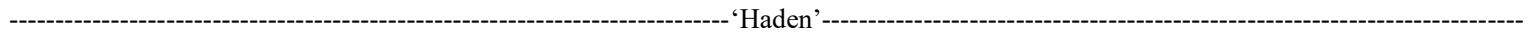 } \\
\hline Air & $0.29 \mathrm{a}^{/ 1}$ & $31.5 \mathrm{a}$ & $0.549 \mathrm{a}$ & $0.088 \mathrm{~ns}$ & $2.98 \mathrm{a}$ \\
\hline $2 \mathrm{kPa} \mathrm{O}_{2}$ & $0.14 \mathrm{ab}$ & $17.4 \mathrm{ab}$ & $0.291 \mathrm{ab}$ & 0.049 & $1.50 \mathrm{ab}$ \\
\hline $5 \mathrm{kPa} \mathrm{O}_{2}$ & $0.07 \mathrm{~b}$ & $8.2 \mathrm{~b}$ & $0.129 \mathrm{~b}$ & 0.031 & $0.51 \mathrm{~b}$ \\
\hline $25 \mathrm{kPa} \mathrm{CO}$ & $0.13 \mathrm{ab}$ & $16.7 \mathrm{ab}$ & $0.296 \mathrm{ab}$ & 0.093 & $1.48 \mathrm{ab}$ \\
\hline $\mathrm{CV}^{/ 2}$ & 82.22 & 91.63 & 79.63 & 85.76 & 82.98 \\
\hline \multicolumn{6}{|c|}{ - } \\
\hline Air & $1.49 \mathrm{~ns}^{/ 3}$ & $9.80 \mathrm{~ns}$ & $0.154 \mathrm{~ns}$ & $0.019 \mathrm{~ns}$ & $0.85 \mathrm{~ns}$ \\
\hline $2 \mathrm{kPa} \mathrm{O}_{2}$ & 1.65 & 8.88 & 0.180 & 0.015 & 1.00 \\
\hline $5 \mathrm{kPa} \mathrm{O}_{2}$ & 0.97 & 6.31 & 0.111 & 0.004 & 0.59 \\
\hline $25 \mathrm{kPa} \mathrm{CO} 2$ & 1.19 & 8.86 & 0.152 & 0.015 & 0.80 \\
\hline $\mathrm{CV}^{/ 3}$ & 47.35 & 68.58 & 67.29 & 122.85 & 68.7 \\
\hline
\end{tabular}

$/{ }^{1}$ Averages followed by the same letter in columns for each cultivar do not differ statistically at Tukey's multiple range test $(\mathrm{P}<.05)$.

${ }^{12} \mathrm{CV}=$ variation coefficient.

${ }^{1 / 3} \mathrm{~ns}=$ differences in averages not statistically significant.

(Table 4) and 'Keitt' (Table 2) mangoes. TAMURA et al. (2001) indicated that cultivar differences are the major factor for those differences in terpenes and oxygenated aroma compounds such as hexanal. Nonetheless, the elevated $\mathrm{CO}_{2}$ atmospheres might have an influence on the synthesis of these $\mathrm{C}_{6}$ hydrocarbons as they probably derive, according to BANDYOPADHYAY \& GHOLAP (1973) from fatty acid lipid peroxidation. Lipid components and their breakdown to fatty acids have been considered to be the main precursors of volatiles in mangoes and in fruits in general (SELVARAJ et al., 1989). It is generally recognized that the sesquiterpene hydrocarbons are derived from acetyl-CoA through the mevalonic acid (MVA) pathway in the cytosol (SHARON-ASA et al., 2003; YU et al., 2015).

In addition to differences between cultivars, there was also a significant difference in acetaldehyde peak height among the storage atmosphere treatments. Both 'Haden' mangoes stored for 14 days at $15^{\circ} \mathrm{C}$ and 'Tommy Atkins' mangoes stored for 21 days at $12{ }^{\circ} \mathrm{C}$ in the $2 \mathrm{kPa}$ $\mathrm{O}_{2}$ atmosphere had the highest acetaldehyde peaks for each cultivar (Table 4). Fruit from the $2 \mathrm{kPaO}_{2}$ treatment for both cultivars also had the highest ethanol production rates as already previously observed (BENDER et al., 2000b) with 'Tommy Atkins' having much higher ethanol levels than 'Haden'. This is an indication that reduction of the $\mathrm{O}_{2}$ partial pressure in the storage atmosphere for mangoes affects fermentative metabolism not only by stimulating alcohol dehydrogenase, but also pyruvate decarboxylase, as observed by $\mathrm{KE}$ et al. (1993) in strawberries and by KE et al. (1995) in avocados.

MacLEOD \& SNYDER (1985), when examining aroma profiles of 'Keitt' mangoes, questioned whether ethanol and, consequently, acetaldehyde are true components of mango flavor. It seems, though, that these components are, in fact, components of mango aroma considering that acetaldehyde and ethanol were determined at the beginning of ripening and before storage of $\mathrm{cv}$. Keitt mangoes (Table 2) contrasting with the statement of MacLEOD \& SNYDER (1985) that only stored or overripe mangoes produce ethanol. Furthermore, data from mature green cv. Kent (not discussed in the present paper) indicated the presence of acetaldehyde and ethanol at the beginning of storage.

In addition to oxygen partial pressure in the storage atmosphere, storage temperature also influences anaerobic metabolism. As described in BENDER et al. (2000a), there is a significant 
Table 4 - Aroma compounds in mesocarp tissue of harvested mature-green cv. Haden and Tommy Atkins mangoes at transfer to $20{ }^{\circ} \mathrm{C}$ air from storage or in $\mathrm{CA}$ of $5 \mathrm{kPa} \mathrm{O}$ plus $10 \mathrm{kPa}$ or $25 \mathrm{kPa} \mathrm{CO}_{2}$ for 2 weeks at $15^{\circ} \mathrm{C}$ or 3 weeks at $12{ }^{\circ} \mathrm{C}$, respectively.

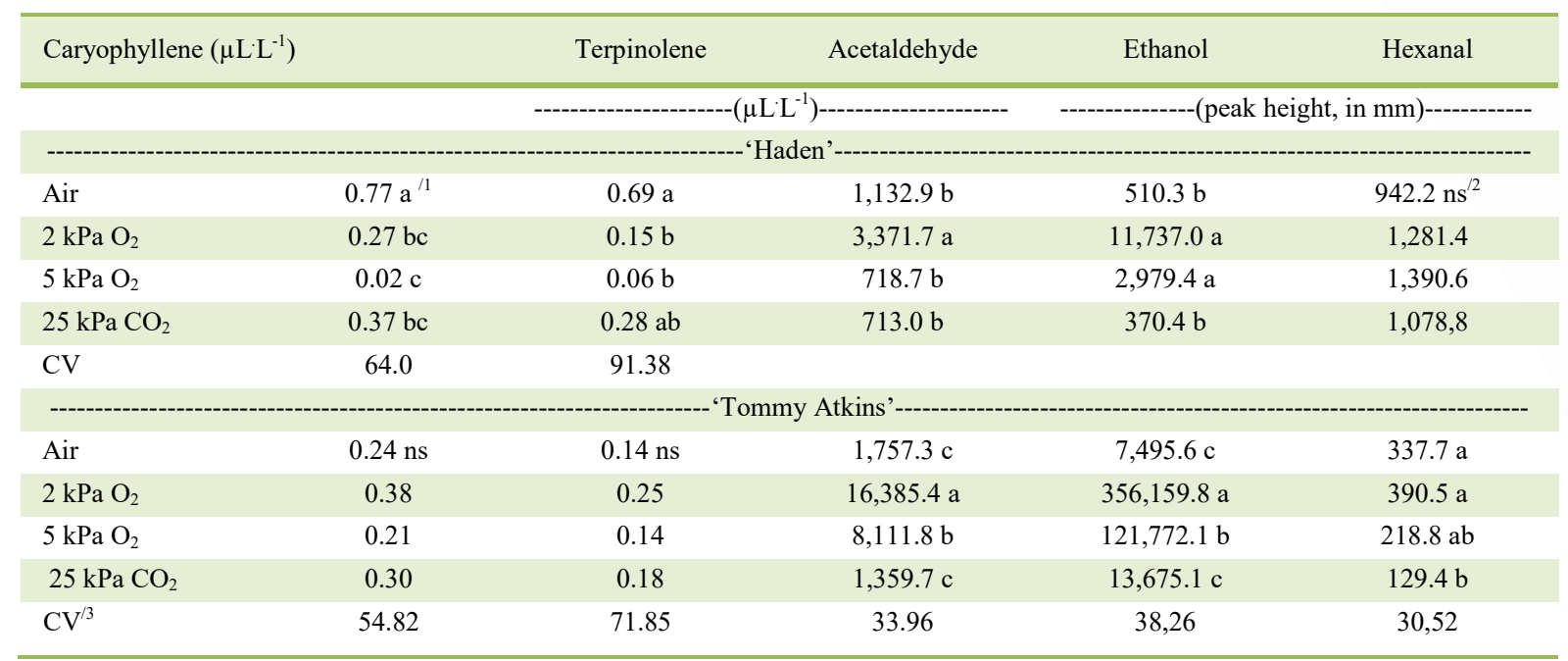

${ }^{1}$ Averages followed by the same letter in columns for each cultivar do not differ statistically at Tukey's multiple range test $(\mathrm{P}<.05)$

${ }^{/ 2} \mathrm{~ns}=$ differences in averages not statistically significant.

${ }^{13} \mathrm{CV}=$ variation coefficient.

increase in acetaldehyde production rates of treeripe 'Tommy Atkins' mangoes during storage for 3 weeks at $8{ }^{\circ} \mathrm{C}$ in comparison to a $12{ }^{\circ} \mathrm{C}$-storage. Moreover, in that paper tree-ripe 'Tommy Atkins' fruit stored at $12{ }^{\circ} \mathrm{C}$ had acetaldehyde production rates similar to mature-green fruit stored under the same storage conditions.

Biosynthesis of some terpenes in mangoes stored in elevated $\mathrm{CO}_{2}$ atmospheres was not altered in mature green or tree ripe cv. Tommy Atkins mangoes stored at either $8{ }^{\circ} \mathrm{C}$ or $12^{\circ} \mathrm{C}$ (Table 5) and tree ripe cv. Keitt mangoes stored at $5{ }^{\circ} \mathrm{C}$ or $8{ }^{\circ} \mathrm{C}$ (Tables 1 and 2). In the paper BENDER et al. (2000a) and under the same storage procedures, we concluded that the $5 \mathrm{kPa} \mathrm{O}_{2}$ plus $25 \mathrm{kPaCO}_{2}$ treatment seemed to have different effects on the biosynthesis of aroma compounds, such as $\alpha$-pinene and 3-carene, depending on the ripeness stage of the fruit. In the early stages of ripening (i.e., mature-green fruit), exposure to the higher $\mathrm{CO}_{2}$ storage atmosphere might have a greater effect on the synthesis of certain volatile compounds than exposure at later stages, which could lead to poor flavor after transfer to air. With tree-ripe fruit, the same atmosphere in association with the $5{ }^{\circ} \mathrm{C}$ storage temperature might prevent the breakdown and also the synthesis of a few other compounds, like $P$-cymene (Tables 1 and
2), which could impart an uncharacteristic flavor to the mangoes stored under those conditions.

Nevertheless, there is still much left to investigate in terms of specific pathways leading to important compounds for the aroma of mangoes. How each one is regulated and responds to CA and low temperatures needs further investigation dependent on the elucidation of the pathways.

\section{CONCLUSION}

Terpene synthesis by 'Keitt', 'Haden' and 'Tommy Atkins' mangoes in air or CA storage varied significantly, preventing generalizations as to what storage conditions favor or limit aroma components elution. The component that has been determined to be the most abundant in these cultivars is 3-carene. Among the aroma compounds analyzed, $P$-cymene biosynthesis in 'Keitt' mangoes seemed to be most sensitive to storage in the injurious $25 \mathrm{kPa} \mathrm{CO}_{2}$ atmosphere. The $25 \mathrm{kPa} \mathrm{CO}_{2}$ treatment at $5^{\circ} \mathrm{C}$ had the most pronounced effect on the aroma profile of 'Keitt' mangoes, which suggested that this treatment causes damage that severely impairs mango ripening after transfer to air. Storage of mature-green 'Haden' and 'Tommy Atkins' fruit in $2 \mathrm{kPa} \mathrm{O}_{2}$ resulted in elevated fermentative metabolism. 
Table 5 - Aroma compounds ( $\mu$ L.L-1) in mesocarp tissue of mature green (MG) or tree ripe (TR) cv. Tommy Atkins mangoes after 2 days in air at $20^{\circ} \mathrm{C}$ following a 21 -day storage in $\mathrm{CA}(5 \mathrm{kPa} \mathrm{O} 2$ plus $10 \mathrm{kPa}$ or $25 \mathrm{kPa} \mathrm{CO} 2)$ or air at $8{ }^{\circ} \mathrm{C}$ or $12{ }^{\circ} \mathrm{C}$.

\begin{tabular}{|c|c|c|c|c|}
\hline & Caryophyllene & $\beta$-pinene & Myrcene & Terpinolene \\
\hline Air & $0.377 \mathrm{~ns} / 1$ & $0.250 \mathrm{~ns}$ & $1.393 \mathrm{~ns}$ & $0.280 \mathrm{~ns}$ \\
\hline $10 \mathrm{kPaCO} 2$ & 0.713 & 0.287 & 1.530 & 0.353 \\
\hline $25 \mathrm{kPaCO} 2$ & 0.277 & 0.100 & 3.933 & 0.170 \\
\hline \multicolumn{5}{|c|}{ - } \\
\hline Air & 1.403 & 0.887 & 7.447 & 1.907 \\
\hline $10 \mathrm{kPaCO} 2$ & 0.720 & 0.597 & 5.250 & 1.080 \\
\hline $25 \mathrm{kPaCO} 2$ & 1.767 & 1.060 & 6.097 & 1.257 \\
\hline \multicolumn{5}{|c|}{ 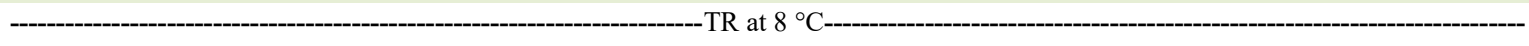 } \\
\hline Air & 0.640 & 0.677 & 4.530 & 1.040 \\
\hline $10 \mathrm{kPa} \mathrm{CO} 2$ & 0.597 & 0.590 & 5.410 & 1.417 \\
\hline $25 \mathrm{kPa} \mathrm{CO} 2$ & 0.663 & 0.287 & 1.927 & 0.533 \\
\hline $\mathrm{CV} / 2$ & 74.3 & 84.69 & 83.41 & 85.15 \\
\hline
\end{tabular}

${ }^{/ 1} \mathrm{~ns}=$ differences in column averages not statistically significant.

${ }^{12} \mathrm{CV}=$ coefficient of variation.

\section{ACKNOWLEDGEMENTS}

Scholarship for doctoral studies of the first author by the Coordenação de Aperfeiçoamento de Pessoal de Nível Superior (CAPES), Brazil.

\section{DECLARATION OF CONFLICT OF INTEREST}

The authors declare no conflict of interest.

\section{AUTHORS' CONTRIBUTIONS}

RJB and JKB conceived and designed experiments RJB performed the experiments, carried out the lab analyses and performed statistical analyses of experimental data. RJB prepared the draft of the manuscript. JKB and EZB critically revised the manuscript and approved of the final version.

\section{REFERENCES}

ADEDEJI, J. et al. Characterization of glycosidically bound aroma compounds in the African mango (Mangifera indica L.). Journal of Agricultural and Food Chemistry, v.40, p.659-661, 1992. Available from: <http://dx.doi.org/10.1021/jf00016a028>. Accessed: Jul. 17, 2020.

BALDWIN, E. A. et al. Quantitative analysis of flavor and other volatiles and for certain constituents of two tomato cultivars during ripening. Journal of the American Society for Horticultural Science, v.116, v.2, p.265-269, 1991. Available from: < http:// dx.doi.org/10.21273/JASHS.116.2.265>. Accessed: Jul. 17, 2020.
BALOCH, M. K.; \& BIBI, F. Effect of harvesting and storage conditions on the post-harvest quality and shelf life of mango (Mangifera indica L.) fruit. South African Journal of Botany, v.83, p.109-116, 2012. Available from: <http://dx.doi. org/10.1016/j.sajb.2012.08.001>. Accessed: Jul. 17, 2020.

BANDYOPADHYAY, C.; \& GHOLAP, A. S. Relationship of aroma and flavor characteristics of mango (Mangifera indica $\mathrm{L}$ ) to fatty acid composition. Journal of the Science of Food and Agriculture, v.2, p.1497-1503, 1973. Available from: <http:// dx.doi.org/10.1002/jsfa.2740241205>. Accessed: Jul. 17, 2020.

BARTLEY, P.; \& SCHWEDE, A. Volatile flavor components in the headspace of the Australian 'Bowen' mango. Journal of Food Science, v.52, n.2, p.353-360, 1987. Available from: $<$ http://dx.doi. org/10.1111/j.1365-2621.1987.tb06611.x>. Accessed: Jul. 18, 2020.

BENDER, R. J. et al. Aroma volatiles of mature-green 'Tommy Atkins' mangoes after controlled atmosphere vs. air storage. HortScience, v.35, p.684-686, 2000a. Available from: <http:// dx.doi.org/10.21273/HORTSCI.35.4.684>. Accessed: Jul. 18, 2020.

BENDER, R. J. et al. Mango tolerance to reduced oxygen levels in controlled atmosphere storage. Journal of the American Society, v.125, n.6, p.709-713, 2000b. Available from: <http://dx.doi. org/10.21273/JASHS.125.6.707>. Accessed: Jul. 18, 2020.

BRECHT, J. K. Mango: Requirements and recommendations. In: R. BEAUDRY, R.; \& GIL, M. I. Controlled and Modified Atmosphere for Fresh and Fresh-Cut Produce. Cambridge, Academic Press, 2020. p.363-372. Accessed: Jul. 18, 2020.

ENGEL, K. H.; \& TRESSL, R. Studies on the volatile components of two mango varieties. Journal of Agricultural and Food 
Chemistry, v.31, n.4, p.796-801, 1983. Available from: <http:// dx.doi.org/10.1021/jf00118a029>. Accessed: Jul. 18, 2020.

GOSWAMI, T. K.; \& RAVINDRA, R. Determination of aroma volatiles in mango fruit cv. Amrapali as affected during storage under rapid controlled atmosphere conditions using liquid Nitrogen. International Journal of Agriculture, Environment and Biotechnology, v.6, n.3, p.471-478, 2013. Available from: <http:// dx.doi.org/ 10.5958/j.2230-732X.6.3.020>. Accessed: Dec. 02, 2020.

IDSTEOM, H.; \& SCHREIER, P. Volatile constituents of Alphonso mango (Mangifera indica L.). Phytochemistry, v.24, n.10, p.3132316, 1985. Available from: <http.dx.doi.org/10.1016/S00319422(00)83033-2>. Accessed: Jul. 18, 2020.

KE, D. et al. Anaerobic metabolism of strawberries under elevated and reduced atmospheres. Acta Horticulturae, v.343, p.93-99, 1993. Available from: <https://doi.org/10.17660/ ActaHortic.1993.343.23>. Accessed: Jul. 18, 2020.

KE, D. et al. Regulation of fermentative metabolism in avocado fruit under oxygen and carbon dioxide stresses. Journal of the American Society for Horticultural Science, v.120, n.3, p.481-490, 1995. Available from: <http://dx.doi.org/10.21273/ JASHS.120.3.481>. Accessed: Jul. 18, 2020.

LALEL, H. et al. Maturity stage at harvest affects fruit ripening, quality and biosynthesis of aroma volatile compounds in 'Kensington Pride' mango. Journal of Horticultural Science and Biotechnology, v.78, n.2, p.225-233, 2003. Available from: $<$ http://dx.doi: 10.1080/14 620316.2003.11511610>. Accessed: Jul. 17, 2020.

LEBRUN, M. et al. Discrimination of mango fruit maturity by volatiles using the electronic nose and gas chromatography. Postharvest Biology and Technology, v.48, n.1, p.122131, 2008. Available from: <http://dx.doi.org/10.1016/j. postharvbio.2007.09.010>. Accessed: Jul. 18, 2020.

LI, L. et al. Profiling of volatile fragrant components in a minicore collection of mango germplasms from seven countries. PLoS ONE, v.12, p.1-14, 2017. Available from: <http://dx.doi. org/10.1371/journal.pone.0187487>. Accessed: Dec. 02, 2020.

MacLEOD, A. J.; PIERIS, N. M. Comparison of the volatile components of some mango cultivars. Phytochemistry, v.23, n.2, p.361-366, 1984. Available from: <http://dx.doi.org/10.1016/ S0031-9422(00)80333-7>. Accessed: Jul. 18, 2020.

MacLEOD, A. J.; SNYDER, C. H. Volatile components of two cultivars of mango cultivars from Florida. Journal of Agricultural and Food Chemistry, v.33, n.3, p.380-384, 1985. Available from: $<$ http: dx.doi.org/10.1021/jf00063a015>. Accessed: Jul. 18, 2020.

MALUNDO, T. M. M. et al. Method for the rapid headspace analysis of mango (Mangifera indica L.) homogenate volatile constituents and factors affecting quantitative results. Journal of Agricultural and Food Chemistry, v.45. n.6, p.2187-2194, 1997. Available from: $<$ https://doi.org/10.1021/jf960569c >. Accessed: Jul. 18, 2020.

MILLER, W. R. et al. Film wrapping mangos at advancing stages of post-harvest ripening. Tropical Science, v.26, p.917, 1986. Available from: <http://europepmc.org/article/AGR/ ADL86048360>. Accessed: Jul. 18, 2020.

MONACO, K. A. et al. Influence of ozonated water sanitation on postharvest quality of conventionally and organically cultivated mangoes after postharvest storage. Postharvest Biology and Technology, v.120, p.69-75, 2016. Available from: <http://dx.doi. org/10.1016/j.postharvbio.2016.05.003>. Accessed: Dec. 01, 2020.

MUNAFO, J. P. et al. Insights into the key aroma compounds in mango (Mangifera indica L. 'Haden') fruits by stable isotope dilution quantitation and aroma simulation experiments. Journal of Agricultural and Food Chemistry, v.64, n.21, p.43124318, 2016. Available from: <http://dx.doi.org/10.1021/acs. jafc.6b00822>. Accessed: Dec. 02, 2020.

PANDIT, S. S. et al. Changes in volatile composition during fruit development and ripening of 'Alphonso' mango. Journal of the Science of Food and Agriculture, v.89, n.12, p.2071-2081, 2009. Available from: $<$ http://dx.doi.org/10.1002/jsfa.3692>. Accessed: Jul. 18, 2020.

SELVARAJ, Y. et al. Changes in sugars, organic acids, amino acids, lipid constituents and aroma characteristics of ripening mango (Mangifera indica L.) fruit. Journal of Food Science and Technology, v.26, p.308-313, 1989. Accessed: Jul. 17, 2020.

SHARON-ASA, L. et al. Citrus fruit flavor and aroma biosynthesis: isolation, functional characterization, and developmental regulation of Cstps1, a key gene in the production of the sesquiterpene aroma compound valencene. The Plant Journal, v.36, p.664674, 2003. Available from: <http://dx.doi.org/10.1046/j.1365313X.2003.01910.x>. Accessed: Dec. 02, 2020.

SINGH, S. P.; \& SAINI, M. K. Postharvest vapor heat treatment as a phytosanitary measure influences the aroma volatiles profile of mango fruit. Food Chemistry, v.164, p.387-395, 2014. Available from: <http:// dx.doi.org/10.1016/j.foodchem.2014.05.009>. Accessed: Dec. 02, 2020.

SIVAKUMAR, D. et al. Maintaining mango (Mangifera indica L.) fruit quality during the export chain. Food Research International, v.44, n.5, p.1254-1263, 2011. Available from: <http://dx.doi. org/10.1016/j.foodres.2010.11.022>. Accessed: Dec. 02, 2020.

TAMURA, H. et al. The volatile constituents in the peel and pulp of a green Thai mango, Khieo Sawoei cultivar (Mangifera indica L.). Food Science and Technology Research, v.7, n.1, p.72-77, 2001. Available from: <http://dx.doi.org/10.3136/fstr.7.72>. Accessed: Dec. 01, 2020.

ULLAH. H. et al. Storage of ripe mango (Mangifera indica L.) cv. Alphonso in controlled atmosphere with elevated $\mathrm{CO}_{2}$. Pakistan Journal of Botany, v.42, n.3, p.2077-2084, 2010. Available from: $<$ https://www.researchgate.net/publication/267982629_Storage_ of_ripe_mango_Mangifera_Indica_L_cv_alphonso_in_controlled_ atmosphere_with_elevated_CO2>. Accessed: Dec. 02, 2020.

WILSON, C. W. et al. Importance of some lactones and 2,5-dimethyl-4-hydroxy-3(2H)-furanone to mango (Mangifera indica L.) aroma. Journal of Agricultural and Food Chemistry, v.38, n.7, p.1556-1559, 1990. Available from: <http://dx.doi. org/10.1021/jf00097a028>. Accessed: Jun. 18, 2020.

YU, Q. et al.. Proteomic and metabolomic analyses provide insight into production of volatile and non-volatile flavor components in mandarin hybrid fruit. BMC Plant Biology, v.15, e76, 2015. Available from: <http://dx.doi.org/10.1186/s12870-015-0466-9>. Accessed: Dec. 02, 2020.

ZAFAR, T. A.; \& SIDHU, J. S. Composition and nutritional properties of mangoes. In: SIDDIQ, M. et al. Handbook of mango fruit: Production, postharvest science, processing technology and nutrition. Hoboken, John Wiley \& Sons, 2017. p.217-236. Accessed: Jan. 01, 2021. 